\title{
DE ZANGSTEM, ONZEGBAAR FASCINANS
}

\author{
Herman Van Campenhout
}

\section{Thematiek en opzet}

Behalve de blik is wellicht niets zo volstrekt singulier als de menselijke stem. Je hoeft niet eens een scherp en geoefend oor te hebben, het volstaat enigermate met iemand vertrouwd te zijn om hem of haar aan de stem te herkennen : ze is als een vingerafdruk, als een genetische signatuur. Voor muziekliefhebbers geldt dat vaak evenzeer voor de stemmen van zangers en zangeressen. In mijn ervaring klinken de stemmen van Giuseppe di Stefano en Victoria de los Angeles - om slechts deze twee voorbeelden te geven - als unieke portretten. Ze hebben iets fascinerends en ik hou ervan. Anderen zullen mijn voorkeur wellicht niet delen. Dat is nu eenmaal zo. Je houdt van een stem of je houdt er niet van, er is nauwelijks een middenweg tussen de fascinatie die tot liefde leidt en de zakelijke herkenning van het singuliere stempel. Je kiest immers je liefde niet, je wordt er door gekozen. De stem treft je, ze raakt iets diep in je - zoals het heet - en je houdt ervan. Daarom heeft het ook niet veel zin met andere melomanen te redetwisten over de waarde van een stem. Je kan er wel begrip voor opbrengen dat een ander verliefd is op een stem, maar je kan zijn gefascineerde voorkeur toch niet delen. Wanneer er één muziekesthetisch terrein is, waarvan bij uitstek met waarheid kan gezegd worden : de gustibus non disputandum, dan lijkt het me het domein van de zangstemmen te zijn.

Mijn liefdes of voorkeuren hebben misschien een discutabel of zelfs bedenkelijk karakter. Dat kan ik dan niet helpen. Zo houd ik van de los Angeles, ook als ze Carmen zingt, een rol waarvoor velen haar stem - waarschijnlijk terecht niet bijzonder geschikt achten. En ik houd van di Stefano, ook als hij Verdi zingt, al weet ik maar al te goed dat deze tenor een zwak stilist is, die steeds zichzelf zingt en zich weinig bekommert om de letter van Verdi's schriftuur. Ik weet dat Bergonzi, van wie ik evenzeer hou, als trouw Verdiaan vermoedelijk wel veel dichter het 'ideaal' van de componist zal benaderen, en dat di Stefano er geregeld met zijn muts naar gooit. Mijn voorkeur voor Bergonzi kan ik dan ook enigermate met muzikale argumenten verantwoorden, mijn liefde voor di Stefano enkel bekennen.

$\mathrm{Er}$ is nog iets heel anders en merkwaardigs vast te stellen. Hoe irrationeel mijn liefde ook moge zijn, ze wordt door velen gedeeld, en daar ben ik best tevreden mee. Althans het muzikale object van mijn liefde wil ik graag met anderen delen. 
Ik vermoed dat gelijkaardige dingen kunnen gezegd worden in verband met de zogenaamd populaire muziek. Popliefhebbers hebben immers ook hun voorkeuren. Ze voelen een bijzondere voorkeur voor - zeg maar - Bob Dylan of Macy Gray, maar dan niet voor Axelle Red of Elton John, of omgekeerd. Telkens is het die ene stem die het hem doet. Het is dan ook niet toevallig dat een groep meestal rond een lead-singer is georganiseerd, want het is de singuliere stem die de populariteit fundeert en gaande houdt. Net zoals de diva's uit de opera-wereld in verleden en heden gevierde en beminde reputaties waren en zijn, brengen ook beroemde pop-sterren telkens duizenden op de been. Men weet dat dit wel eens tot krankzinnige toestanden leidt. Dat is dan tenminste gedeeltelijk ook op rekening te schrijven van de fascinatie door de stem.

Het is een gewoon ervaringsgegeven dat er een betoverende aantrekkingskracht van stemmen kan uitgaan. Het hoeft daarbij niet eens om individuele stemmen te gaan. Je kan ook in de ban komen van een groep als de King's Singers of van een koor met diepe basstemmen in Russisch-orthodoxe kerkzangen. Meestal gaat de verlokking echter wel degelijk uit van een individuele stem. Op de keper beschouwd is dit gewone ervaringsgeven erg vreemd. We hebben niet direct een verklaring voor het feit dat een stem de mensen zo sterk aanspreekt dat ze hen kan verrukken, in vervoering kan brengen, zelfs tot op de rand - of er net overheen - van een dionysische zinsverbijstering. Dat is uiteraard allemaal irrationeel, maar toch niet meer irrationeel dan het algemeen als gelukkig geprezen gebeuren dat je op iemand verliefd wordt.

Het fenomeen heeft inderdaad iets van verliefdheid, van de erotische waanzin die ons buiten onszelf kan brengen. En die verliefdheid kan een langdurige aangelegenheid zijn, ze kan getransformeerd tot wat men meestal liefde noemt, en dan een blijvender karakter aannemen. Het is dan ook heel terecht dat we zeggen: ik ben verliefd op die stem, of ik hou ervan. Het onderscheid met verliefdheid of liefde springt echter onmiddellijk in het oog. We zijn altijd met velen zelden alleen - om van een stem te houden, terwijl iemand toch niet direct de verliefde gevoelens van velen uitlokt. Het falling in love treft telkens één persoon, maar het zijn er velen die vallen voor een stem. Toch bestaat er alweer een parallellisme, in zover we in beide gevallen met de mond vol tanden staan, wanneer men ons vraagt waarom wij die persoon of die stem zo uitzonderlijk vinden. We kunnen enkel bekennen dat ze voor ons iets buitengewoons hebben, maar we kunnen nauwelijks argumenteren waarom dat zo is. Daarbij moeten we wel aan het scholastieke adagium denken : individuum est ineffabile.

Over deze gewone en toch vreemde dingen wil dit essay nadenken.

Maar er is meer.

Je mag wel zeggen, meen ik, dat de stem iets sacraals heeft, of tenminste kan hebben, als ze een belangstelling van bijzondere aard wekt. Minstens één van de 
momenten die volgens Rudolf Otto constitutief zijn voor het heilige, is zeker ook op de stem van toepassing : het fascinans, "het meeslepende, wonderlijk verrukkende, het vaak genoeg tot zwijmel en roes voortjagende, het dionysische van de werkingen van het numen" . En misschien mag men aan de stem nog een ander moment van het heilige toeschrijven, het Griekse deinos, wat Otto vertaalt als ungeheuer, ontzettend, verschrikkelijk ${ }^{2}$. We zullen dat ontzettende op onze zoektocht nog herhaaldelijk ontmoeten.

Dat de stem iets sacraals heeft, dat hebben dichters, religieuze profeten en denkers altijd geweten.

Dichters - zo luidt het aloude verhaal - luisteren naar de stem van de Muze. Homeros laat het voorkomen alsof de door hem aangeroepen Muze doorheen zijn mond de Ilias en de Odyssee zingt. Het zijn duidelijk-niet enkel schizofrenen die stemmen horen. Religieuze profeten als Mozes en Mohammed krijgen openbaringen in de vorm van visioenen, maar daarbij speelde ook een goddelijke stem - een fascinans en een deinos, als er ooit een was - een essentiële rol. In de Brihad-Aranyaka-oepanisjad willen de goden, mensen en duivels de stem van hun vader, Prajapati, de Heer der Schepping, horen, en zij deelt hun de drie funderende houdingen van het ethische leven mee.

Denkers hebben van oudsher gesproken over de stem van het geweten. Reeds Socrates luisterde naar een innerlijke demon die hem waarschuwde dat hij bepaalde dingen niet mocht doen. Rousseau had het over de "onsterfelijke en hemelse stem" die zelfs luider klonk dan de natuurlijke passies. Kant noemde de stem van het geweten unüberschreibar, niet te overschreeuwen. En Heidegger sprak over het geweten als over de roep van een stille stem ${ }^{3}$.

We zitten duidelijk in de dimensie van het fascinans en het deinos. Zou die dimensie van het deinos ook aanwezig zijn bij onze zangers, de los Angeles en di Stefano?

De wijsheid van de wereld weet natuurlijk dat de stem van de Muzen, van God of de goden, en van het geweten als dichterlijke metafoor moet begrepen worden. Dat zal wel. Toch lijkt het nogal vreemd gesteld met die metaforische stemmen die zich als de levende God bekend maken, fundamentele ethische boodschappen meedelen en luidruchtige passies kunnen overschreeuwen. Klaarblijkelijk grijpen die metaforische stemmen machtig in het menselijk bestaan in. Waar komen dergelijke metaforen eigenlijk vandaan ? De stelling dat ze door dromers en dichters zijn uitgevonden, klinkt niet zo overtuigend. Ergens moeten zij die ook gehoord hebben, net zoals zij de namen van de goden en helden, en de verhalen over hen, van anderen vernomen hebben. En waar hebben die anderen dan dit alles vandaan? Tenslotte hebben we te maken met de onbeantwoordbare vraag naar de oorsprong, vooral naar de oorsprong van het zeggen, de taal.

Sommige hedendaagse filosofen spreken graag over inscripties. Duidelijk weer een metafoor : één of andere gebeurtenis, ervaring of betekenaar wordt er- 
gens in ons ingeschreven, zoals een woord op het papier. Men ziet eigenlijk niet goed in hoe om het even wat in ons zou kunnen ingeschreven worden, tenzij het reeds een talig karakter heeft aangenomen, en als men dat aanvaardt, kan een ervaring toch enkel maar een betekenaar worden voor een wezen dat woorden heeft gehoord. Anders gezegd : we kunnen inscripties slechts lezen, voor zover we kunnen spreken, en we kunnen slechts spreken, voor zover we geluisterd hebben naar een stem. Taaldenkers van deze tijd hebben het steeds maar over woorden en betekenaars als zichtbare tekens, en ze vergeten daarbij dat taal vooreerst een hoorbaar fenomeen is. Maar zo is het steeds al geweest in de filosofie : ervaring en werkelijkheid worden primair in visuele termen gedacht, vermoedelijk omdat de mens als hogere primaat een visueel wezen is, dat wil zeggen een wezen waarvoor het oog boven en meer dan de andere zintuigen gebruikt wordt bij de verkenning van zijn werkelijkheid. De auditieve omgang met de wereld valt dan altijd uit de filosofische boot, en alles wordt netjes visueel gedacht, ook de taal die meteen als een geheel van inscripties gearticuleerd wordt. Het is duidelijk dat we ook niet van een stille stem van het geweten kunnen spreken, tenzij we eerst een stem gehoord hebben. De stem lijkt dus veel meer te zijn dan een geluid naast andere geluiden : ze is iets originairs dat ons in het bestaan roept, en de taal wordt vooreerst in het stemgebruik, dus als auditief systeem, geconstitueerd. Het ontbreekt dan ook niet aan mythen die precies zeggen dat een god ons schiep door te spreken, uiteraard met een stem, dat duidelijke fascinans en deinos. Dergelijke mythen worden ook steeds, heel typisch, begrepen als metaforische verklaring voor de mens als talig wezen, waarbij dan de hoorbare stem, de stem die ons in het bestaan roept, niet meer mee-gedacht wordt. Het behoort tot de verdiensten van Jacques Lacan dat hij van de stem tenminste een belangrijk thema van zijn denken heeft gemaakt, ook al heeft hij over onze horende omgang met de wereld, de taal en de begeerte, voor zover ik weet, niet gereflecteerd. En lacanianen hebben ook de gewoonte om over de stem, de hoorbare, in termen van inscriptie te denken, en bevestigen daarmee de denkgewoonte om het hoorbare dus weer tot het zichtbare te herleiden.

Misschien zijn we als talige dieren wel essentieel metaforische wezens, en als dat zo is, dan zijn we dat steeds ook door de stem, en niet enkel door inscripties van een stem.

Het thema van de stem confronteert ons kennelijk met de ganse wijsgerige problematiek van het menselijk bestaan. Een gewicht dat door geen enkel schrijver, en allerminst in een klein essay, kan gedragen worden. Deze verhandeling wil ook enkel een paar gedachten samenlezen over het muzikale fenomeen van de zangstem als onzegbaar fascinans. Daarbij kunnen echter die andere thema's niet helemaal uit het oog verloren worden. 


\section{Over Sirenen, Muzen en Orfeus}

\section{De sirenen}

Homeros laat er geen twijfel over bestaan dat de zang van de Sirenen zowel fascinans als deinos was. De gevolgen van hun oweerstaanbare aantrekkingskracht liegen er niet om, want de Sirenen zijn "gezeten op een weide, waar hoog opgestapeld liggen de rottende beenderen van mannen en lichamen met verschrompelde huid" . Alle omstandigheden werken dan ook samen om de verleiding van de Sirenen te doen lukken. Rond het eiland heerst een benauwende volkomen stilte, die op beangstigende manier plots was ingetreden. "Toen ging de wind plotseling liggen en de zee werd stil, zonder een zuchtje. Een god had de golven in slaap gelegd". Is dit niet reeds een dodelijke stilte ? We zullen het motief van de ondraaglijke stilte nog tegenkomen. In die vreselijke stilte klinken dan de hoge, heldere stemmen van de Sirenen, vrouwelijke en goddelijke wezens. Hun zang belooft aan de voorbijvarende luisteraars "genot en kennis". Genot, dat kunnen we ons wel voorstellen, maar ook kennis wordt in het vooruitzicht gesteld, want de Sirenen "weten alles wat er gebeurt op de vruchtbare aarde". We worden even herinnerd aan de stem van de slang in het aards paradijs. Het is duidelijk dat de Sirenen een stem verlenen aan het begeren. "Mijn hart was verlangend te luisteren" geeft Odysseus dan ook toe. Het begerige hart ziet niet alleen, het hoort ook. Als Circe Odysseus niet gewaarschuwd had, en als hij haar sluwe raad niet had opgevolgd, zou hij aan het dodelijke gevaar niet ontkomen zijn. Wat Odysseus redt, is dat hij nog een andere stem, die van Circe, heeft gehoord.

Dit simpele verhaal bevat heel wat motieven die tot reflectie uitnodigen. Vele commentatoren hebben dan ook hun interpretatielust op dit wonderlijke avontuur kunnen botvieren. Bij de Sirenen en hun betekenis zijn ze allen blijven staan, maar het horen als motief zijn ze - uiteraard, moet men bijna zeggen - vergeten. Met enkele van deze hermeneutici wil ik graag meedenken, om mijn eigen betoog te articuleren.

\section{Adorno}

Adorno levert een lectuur die past bij de ontgoochelde modernist ${ }^{5}$. Horkheimer en Adorno laten het proces van de Verlichting reeds aanvangen met de mythologische verhalen en Adorno's interpretatie van het Sirenen-verhaal illustreert hun desillusie. Voor hem vertegenwoordigt de stem van de Sirenen de verlokking van het archaïsche, van de levende natuur, waaruit de mens zich heeft losgemaakt. De mens moet zich wel tegen de verlokking verzetten om niet als subject in de natuur ten onder te gaan. De ratio moet de natuur wel onttoveren, met 
listen haar macht breken, om het menselijk subject mogelijk te maken, en dat impliceert dat de mens, om zich als zelfstandig suject te handhaven, ook de natuur in zichzelf moet onderdrukken. Begeerte behoort in het denken van Adorno dan ook tot de natuurlijke neigingen. Het menselijk wezen kan dus slechts zijn eigen aard, zijn subjectiviteit, in stand houden, als het de stem van de natuur en van de begeerte - de uiterlijke en de innerlijke natuur in de traditionele voorstelling - aan banden legt. Jammer genoeg heeft de rationele beheersing van de natuur onvermijdelijk droevige gevolgen. Wanneer de mens steeds het verbod op het beloofde heerlijke natuurgeluk respecteert, vervreemdt hij immers gaandeweg van de natuur, zodat hij tenslotte nog nauwelijks haar stem kan horen, en dat is intriestig. "In de burgerlijke geschiedenis" is de Sirenenzang dan ook "al geneutraliseerd tot het heimwee van wie langsvaart". Dat heimwee blijft niettemin de westerse muziekgeschiedenis tekenen. "Sinds de gelukkig-mislukte ontmoeting van Odysseus en de Sirenen hebben alle liederen iets zieks gekregen, en de gehele muziek van het avondland laboreert aan de onzinnigheid van gezang in deze civilisatie, die toch tegelijk weer de drijvende impuls voor alle kunstmuziek vormt", zo besluit de bedroefde modernist.

\section{Blanchot}

Hoe fascinerend ook, volgens Blanchot had de zang van de Sirenen ook iets onvolmaakts. Het was niet door zijn perfecte schoonheid dat hun zang zulke betoverende kracht had, maar door een gebrek. De zang van de Sirenen was slechts "een zang die nog moest komen; zij leidden de zeevaarder naar de ruimte waar zingen echt zou beginnen". En als de verrukte zeeman op de plaats waar de Sirenen woonden, was aangekomen, was ook "de muziek verdwenen", in de akelige stilte van een door de wind onberoerde zee. Vanuit het standpunt van de verleide zeevaarder klopt dat uiteraard, want die is ondertussen met zijn fascinatie de dood ingegaan. De zang der Sirenen wordt slechts gehoord door diegenen die nog niet voorbijgevaren zijn, en na de dood van de betoverden door weer anderen die naderbijkomen. Alleen Odysseus slaagt er inderdaad in te luisteren én voorbij te varen.

Blanchot gaat niet verder in op het gebrek van de Sirenenzang, vermoedelijk omdat voor hem de ruimte waar het zingen echt zou beginnen, pas later door de verhalende literatuur zal veroverd worden. De sluwe Odysseus valt niet als slachtoffer van de Sirenen, aldus Blanchot, maar wordt door hen afgeleid naar een andere navigatietocht, die "van het verhaal, de niet meer onmiddellijke, maar vertelde zang"7. Met andere woorden, de bestemming van Odysseus is dat hij nadien in een verhaal zijn avonturen bezingt. Toch lijkt me de suggestie van Blanchot bijzonder kostbaar, want de zang die effectief tot de dood toe verleidt, kan moeilijk de menselijke zang zijn die ons wel bekoort, maar die ons ook laat 
leven. Was de Sirenenzang onvolmaakt, omdat hij als 'ol. . ddellijke zang' slechts de betovering van de natuur symboliseert, en nog niet de eigen zang der mensen was?

\section{Nietzsche}

Nietzsche spreekt niet over het zingen van de Sirenen, maar alleen over de zang zoals wij die allen kennen. Toch heeft hij nog een duidelijk besef van het demonische gevaar dat achter het zingen kan schuilen, van het deinos, zeg maar. $\mathrm{Bij}$ hem zijn de verhoudingen echter omgekeerd : de zang is voor hem niet een middel in de hand van buitenmenselijke krachten die de mensen in dodelijke vervoering brengen, maar precies een menselijk medium waarmee die krachten betoverd en aan banden gelegd worden. In Die fröhliche Wissenschaft schrijft hij dat het ritme een dwingende kracht uitoefent op ziel en lichaam van de mens. Met het ritme kan de mens bovendien de goden in de ban houden, en van in den beginne maakten de mensen volgens hem dan ook een heel nuttig gebruik van deze bedwingende kracht.

Men trachtte ( de ziel der goden ) dus door het ritme te dwngen en macht over hen uit te oefenen. Men wierp hun de poëzie om als een magische lus. [Maar] er bestond nog een wonderlijker idee en dit heeft wellicht het krachtigst bijgedragen tot het ontstaan van de poëzie. Bij de Pythagoreeërs komt het voor als filosofische leer en als opvoedkundige kunstgreep. Maar al lang voordat er filosofen bestonden, kende men de muziek de kracht toe de affecten te ontladen, de ziel te reinigen, de ferocia animi te verzachten - en wel door het ritmische in de muziek.

Muziek en ritme verrichten wonderen, betoogt Nietzsche, en de verklaring daarvoor is eenvoudig :

Melos betekent volgens zijn wortel een verzachtingsmiddel, niet omdat het zelf zacht is, maar omdat zijn uitwerking zacht maakt. - En niet alleen in het cultische lied, ook bij het wereldlijke lied van de oudste tijden is de veronderstelling aanwezig dat het ritmische een magische kracht uitoefent, bij voorbeeld tijdens het roeien of waterputten : het lied is een betovering van de hierbij werkzaam gedachte demonen, het maakt ze gewillig, onvrij en een werktuig van de mens. (Mijn cursivering.)

Wat op het spel staat in zang en muziek is dus nog wel degelijk het buiten- of onmenselijke, de goddelijke en demonische krachten, maar volgens Nietzsche worden die door de stem en de zang van de mens betoverd. Het melos heeft een bedwingende werking op het buiten-menselijke, het is een verzachtingsmiddel voor het demonische en goddelijke, dat daardoor zijn overmacht, zijn destructieve werking op de mens verliest. Door zijn zangstem bedwingt de mens het niet- 
menselijke. Het wekt dan ook geen verwondering dat Zarathustra zichzelf aanmaant : "Maar wil je niet wenen, niet uitwenen je purperen zwaarmoedigheid, dan zal je moeten zingen, o mijn ziel!"' En wanneer hij op het einde van het derde boek, genezen van een zware crisis, zichzelf ziet opvliegen als een vogel, roept hij zichzelf de supreme wijsheid toe ; "Zing ! spreek niet meer !"10 Want als door het zingen het demonische en goddelijke bedwongen is, leeft de mens heerlijk.

\section{Over nimfen en Muzen}

Keren we even terug naar de mythologische verhalen van de Grieken. Behalve de Sirenen leven daar ook nog andere bekoorlijke vrouwelijke wezens van niet-menselijke, maar goddelijke aard, met name nimfen en Muzen. Zij spreken de mensen toe, ook al kunnen ze vaak niet gezien, maar enkel gehoord worden.

Zoals de Sirenen behoren de nimfen vermoedelijk tot de archaïsche laag van de Griekse mythologie, ze zijn eerder chtonische natuurgodinnen, en ze werden pas later bij de Olympische godenwereld ingelijfd. Nimfen worden wel eens evenals de Muzen - dochters van Zeus genoemd. Hun dansleider is Hermes en hun meesteres Artemis. Daarnaast worden ze ook de voedsters van Dionysos genoemd. Als we aannemen dat in Dionysos ook een oudere chtonische godheid voortleefde die later als zoon van Zeus bij de Olympische goden werd geïntegreerd, beseffen we meteen dat nimfen iets dubbelzinnigs blijven behouden. Behalve wanneer ze zich aan een uitverkorene willen vertonen, blijven Artemis en de nimfen voor de mensen onzichtbaar. Men kan slechts hun stem horen. Zo spreekt Hippolytus in het drama van Euripides Artemis toe :

Mij slechts op aard gewerd die hoge gunst

met $\mathrm{u}$ te $\mathrm{zijn}, \mathrm{u}$ woorden toe te spreken,

en zie ik u niet, uw stemme te horen. ${ }^{11}$

De zichtbaarheid heeft in het Griekse mythologische en dichterlijke denken de hoorbaarheid nog niet verdrongen. Ook als zo belangrijke elementen als goddelijke wezens niet in de zichtbare aanwezigheid vertoeven, blijven ze toch nog steeds als hoorbaar aanwezig zonder dat zulks iets afdoet van de kracht of van de menselijke zin van hun optreden.

Hoewel er ook over een ouder geslacht van Muzen verteld wordt, gelden de Muzen bijna steeds als Olympische godinnen, als kinderen van Zeus en Mnemosyne. Hun aantal was beperkt : meestal wordt er over negen Muzen verhaald. Dat onderscheidt hen van de veel talrijker nimfen. Muze gold dan ook als eigennaam, nimf niet ${ }^{12}$. Muzen spreken dus in eigen naam, met een stem als van een menselijk subject. Sirenen daarentegen zingen samen - als aantal wordt twee, drie, vijf of meer opgegeven. Zij lijken, in tegenstelling tot de Muzen, nog niet toegetreden tot het niveau van singuliere subjectiviteit dat typisch is voor de mensen en 
voor de Olympische goden. Misschien mag men zeggen dat Sirenen eerder ondermenselijk, en Muzen eerder bovenmenselijk waren, dat Sirenen demonisch en destructief waren voor de mensen, en de Muzen eerder bevorderlijk en verheffend. ( In tegenstelling tot de mens waren echter zowel Sirenen als Muzen, als goddelijke wezens, onsterfelijk.) De zang van de Sirenen kon dan ook niet anders dan een gans andere betekenis hebben voor de mensen als de zang van de Muzen. Wat de zang van de Sirenen, door Blanchot onvolmaakt genoemd, betekende, weten we maar al te goed. Wat betekende dan de zang van de Muzen ?

Toen Zeus de wereld geordend had, vroeg hij de andere goden wat er aan al die pracht nog ontbrak, en de goden antwoordden : een stem om zijn heerlijke werken te prijzen ${ }^{13}$. Daarom verwekte Zeus bij Mnemosyne de Muzen : hun zingen en zeggen is als lofprijzing een goddelijke voltooiing van de wereldorde. Of meer wijsgerig uitgedrukt : pas in het zingen en zeggen van de Muzen wordt het zijn wat het - voor de mens uiteraard - echt is, komt het in zekere zin tot zichzelf en wordt het een woonplaats van de mens. De Muzen inspireren dan ook met een hoger en dieper weten, met het hoogste weten dat voor de mens bereikbaar is. ( (Ook de Sirenen beloven de zeevaarders een weten van alles op de aarde.) En Plato noemde de filosofie de hoogste muzenkunst ${ }^{14}$.

De zanger-dichter wordt geïnspireerd door de buiten-menselijke macht van de Muzen, hij wordt aangegrepen en in vervoering gebracht, omdat hij hun stem heeft gehoord. "De dichter is de horende", aldus W.F. Otto ${ }^{15}$, als hij zingt, is het de Muze die in hem zingt; als hij spreekt, is het omdat hij een stem heeft gehoord. In dit verband mag er misschien even aan herinnerd worden dat Homeros een blinde dichter was : het ontbreken van de zichtbaarheid der dingen verhinderde hem niet de grote Griekse dichter te worden, want het diepere weten komt van de stem van de Muze. Het is trouwens opvallend hoeveel helderzienden in de literatuur blind zijn. Dat is niet enkel een mooie paradox. Horend konden ze de werkelijkheid en het leven nog wel degelijk leren kennen. Het is zelfs alsof ze hun diepere weten precies aan hun blindheid danken, aan hun enkel-maar-horen. Met Plato verandert dat, zoals men weet. Voor zijn denken over de werkelijkheid staat het zien centraal. De blinde Homeros moet het van de filosoof dan ook ontgelden : wanneer de poëzie in de ogen van Plato een minderwaardig weten vertegenwoordigt, komt dat misschien ook omdat de stem en de hoorbare wereld door hem ten voordele van de zichtbaarheid wordt opgeofferd : een eidos-denken is een beeld-denken en dat heeft geen stem en geen oren nodig. Plato, de eerste wijsgeer die zijn denken systematisch op schrift stelde, heeft het primaat van het visuele in de filosofie stevig gevestigd. Filosofen, en later ook psychologen, hebben vrijwel steeds het hoorbare in termen van het zichtbare gedacht. Het is niet toevallig - mag men wellicht veronderstellen - dat Nietzsche zich zo sterk tegen de platoonse traditie heeft gekeerd, omdat hij de door de muziek bewogene, de luisterende filosoof was. Na een beluistering van Schuberts klaviersonate in B- 
groot ( D. 960 ) verklaarde Heidegger eens : "Dat kunnen we met de filosofie niet"16. Deze uitspraak houdt wellicht de aanvaarding in dat er een andere logos bestaat, pre-verbaal en niet aan het visuele gekluisterd, en die toch ook een wereld voor de mensen ontsluiert, en dat er een denken mogelijk is waartoe de westerse filosofie, die zich sedert Plato in rationele inzichtelijkheid heeft vastgebeten, geen toegang heeft. Een denken dat de materialiteit van taal en filosofie niet enkel als inscriptie denkt, en waarvoor niet alleen taal en visualiteit constitutief zouden zijn, maar ook het horen. Levinas ziet in het gelaat een niet overstijgbare alteriteit, en daarom zegt hij dat er een dwingend appel van uitgaat; in dezelfde zin zou men misschien ook over de stem kunnen spreken.

\section{Orpheus}

Als mythisch zanger is Orpheus het oerbeeld van alle dichters en musici geworden. Met zijn stem wist hij de natuur tot stille aandacht voor zijn zang te brengen, en zelfs de wilde dieren luisterden zachtzinnig naar zijn zang. Als één van de Argonauten kon hij met zijn lierzang zelfs de Sirenen ontkrachten, zodat de Argonauten hun tocht veilig konden voortzetten. Men denke even terug aan Nietzsche : het melos is een verzachtingsmiddel tegen het demonische. Het loont de moeite, lijkt me, even bij de wonderlijke kracht van Orpheus' zang te blijven stilstaan.

Orpheus is een complexe figuur over wie in de Griekse mythologie vele verhalen worden verteld. Als zoon van de Thrakische koning Oiagros en de Muze Calliope is hij verwant met de wereld van Zeus en van Apollo. Van deze laatste kreeg hij zijn lier, en volgens een ander verhaal was hij zelfs de zoon van Apollo. De Muzen brachten hem de zangkunst bij. Hij is echter ook verwant met de donkere chtonische wereld van de natuur. Er is iets in Orpheus dat hem binnen het gebied van de dubbelzinnige Dionysos voert. In sommige verhalen komt hij in conflict met de Dionysos-cultus, in andere heeft hij zelf de dionysische riten ingevoerd. Iedereen kent zijn levenseinde : hij werd door de Maenaden, dienaressen van Dionysos, verscheurd. Karl Kerenyi besluit zijn duidende uiteenzetting van de Orpheus-mythe dan ook als volgt : "Het hoofd heeft men daar - op het eiland Lesbos - in het Bakcheion, het heiligdom van Dionysos, begraven, de lier in de tempel van Apollo bewaard. Zo behoorde het en zo beantwoordde het aan het Dionysische noodlot en de Apollinische natuur van Orpheus""17.

Orpheus is dus verwant met twee werelden, de natuur en de aarde - het chtonische - enerzijds, de Olympische wereld anderzijds. Hij is dionysisch én apollinisch. Zijn zang wordt dan ook begrepen door de chtonische natuur, de dieren en de Sirenen. Zij horen zijn zang en worden er stil bij. Ook in de donkere onderwereld verliest zijn stem haar betovering niet en ook daar stemt hij de goden goedgunstig. De twee werelden waar hij mee verwant is, hebben gemeenschappelijk 
dat ze een niet-menselijke werkelijkheid vormen, een andere realiteit. Die andere werkelijkheid wordt door zijn zang zo gefascineerd en beroerd, dat zij bezworen en tot rust gebracht wordt, verzacht, om met Nietzsche te spreken. Men kan slechts vermoeden dat zijn zang die verzachtende kracht aan zijn muzische inspiratie ontleent, dat ze dus moet verklaard worden door zijn deelachtigheid aan de Olympische wereld. Ik expliciteer dit even.

Orpheus' zang zou op de andere, donkere werkelijkheid niet zulk een verzachtende werking kunnen uitoefenen, als hij met die andere werkelijkheid geen enkele verwantschap. kende. De bedwingende betovering komt uiteraard niet van het duistere chtonische zelf; ze komt uit de orde van de Muzen. Men moet het zich dus wel zo voorstellen dat in zijn stem nog iets van de duistere natuurstem aanwezig is en doorklinkt, maar dat die donkere natuurstem in zijn zang reeds door muzische invloed getransformeerd is. Enkel daardoor kan hij de natuurstem tot zwijgen brengen. Wanneer Nietzsche het had over de verzachtende werking van het melos, maakte hij geen onderscheid tussen de goden en de demonen. Hij vergat even dat de goddelijke Muzen in de hem dierbare Griekse mythologie voor de dichter-zangers weldadig kunnen zijn, dat de Muzen in de zang zelf aanwezig zijn en zo het buiten-menselijke in de zin van het demonische op afstand houden. Mijn correctie op de Nietzsche-passage lijkt me overigens niet in tegenspraak met de algemene teneur van Nietzsches denken. Als men de zang van de Sirenen met de zang van Orpheus vergelijkt, moet er dus een zekere metamorfose hebben plaatsgehad : zijn eigen zang behield wel iets van de chtonische zang van de Sirenen, maar had toch ook een wézenlijke verandering ondergaan, zodat zijn zingen nog steeds door de Sirenen begrepen werd, maar tegelijk hun destructieve kracht kon bezweren. De zang van de Sirenen was inderdaad, zoals Blanchot opmerkte, niet volmaakt, hij was nog niet menselijk. Dat is pas de muzisch geïnspireerde zang van Orpheus, die het demonische verzacht.

Het lijkt erop alsof we ons ondertussen heel ver van di Stefano en de los Angeles hebben verwijderd, maar dat is niet helemaal zo. We vertrokken van de vaststelling dat vele mensen door de stemmen van deze zangers op vreemde manier werden gefascineerd. We suggereerden dat de betovering door de stem iets had van het sacrale fascinans en zelfs van het deinos. Zo kon ook enigszins begrijpelijk worden dat men aan de stem vaak een goddelijke kwaliteit heeft toegekend. Mozes en Mohammed hoorden de stem van God die hen tot profeten maakte. En de stem van het geweten maant ons aan tot een ommekeer van de ziel, tot een leven in deugd. Dezelfde thema's hoorden we in de Griekse mythologische verhalen over de Sirenen, de Muzen en Orpheus. Daarin vernamen we zo iets als een verklaring van de fascinatie die van een stem kan uitgaan. De stem bleek inderdaad iets goddelijks te laten horen. In de zangstem klinkt nog iets door van een andere, niet-menselijke wereld, die voor het menselijk subject wel eens bedreigend en vernietigend kan zijn. Maar tegelijk wordt het bedreigende 
door de muzische zang bezworen, verzacht, zoals Nietzsche zei. We begrijpen ondertussen misschien ook beter waarom Blanchot de zang der Sirenen onvolmaakt noemde. Een zang die voor het menselijk subject vernietigend is, kan men inderdaad moeilijk volmaakt noemen. Zulk een zang moet in een andere ruimte gemetamorfoseerd worden. Een zang echter die, geïnspireerd door de Muzen, de vernietigende verlokking op afstand houdt, die het demonische verzacht, heeft deze metamorfose reeds ondergaan en wordt gezongen in wat Blanchot een andere ruimte noemt, een ruimte waarin de mens kan leven en zingen als Zarathustra. Dat is ook de ruimte waarin de los Angeles en di Stefano zingen, en ons alleszins bekoren en fascineren. Of in die ruimte nog iets kan meeklinken van het demonische andere, het deinos, of we in die bekoring nog iets horen van het destructieve van de Sirenen, zullen we via een nieuwe benadering proberen te articuleren.

\section{Lacan en de stem als 'objet petit a'}

In de volgende bladzijden zou ik willen wijzen op een hedendaagse theorie die de thematiek van de mythologische verhalen met andere woorden en begrippen in een niet-mythisch kader herneemt. Deze theorie is van Jacques Lacan. Om voor lezers met een allergie voor de cryptische en paradoxale lacaniaanse ideeenwereld de verdere lectuur van dit essay niet te verzuren, zal ik trachten enkele samenhangen te verduidelijken in een taal die door de Franse psychoanalyticus wellicht zou afgewezen worden. Tot slot kunnen we dan nog eens naar de los Angeles en di Stefano terugkeren ${ }^{18}$.

In de bestaansstructuur van de mens als wezen van begeerte neemt het objet (petit) $a$ - of gewoon petit $a$ - een centrale plaats in : het vormt een knooppunt tussen de drie orden die volgens Lacan het begerende leven articuleren. Het imaginaire vormt de speculaire of narcistische orde waar het subject vergeefs zijn begeerte in zijn greep probeert te houden; het is het terrein van wishful thinking, van de wensconstructies die mensen veelal hun werkelijkheid noemen. Het symbolische is de orde van de taal en haar betekenaars, en van de wetten. Deze orde blijft de vervulling van de begeerte steeds uitstellen, maar tegelijk houdt ze het verlangen in stand en maakt het pas mogelijk ${ }^{19}$. Het lacaniaanse reële valt helemaal niet samen met wat gewoonlijk de realiteit wordt genoemd : het is de orde van het niet-zegbare, van wat steeds aan de betekenaars van de symbolische orde ontsnapt, en het vertegenwoordigt de brute contingentie. In het register van het reële verschijnt dan ook la Chose, de onbenoembare verschrikking van het onvergetelijke, maar onherroepelijk verloren object van de begeerte. Het objet petit $a$ verwijst dan ook niet naar een reëel object of naar een fenomenaal optredende werkelijkheid, maar naar een niet-objectief voorwerp, dat slechts kan waargenomen worden met een schuine of anamorfotische ${ }^{20}$ blik, met de blik van de be- 
geerte als tekort-aan-zijn. Met enige nuances mogen wij het petit a net als la Chose wellicht omschrijven als apriorivormen, als transcendentale mogelijkheidsvoorwaarden voor al de lotgevallen en ervaringen van het begerende subject met zijn objecten ${ }^{21}$. Het objet $a$ staat - mag ik wellicht voorstellen - voor elk mogelijk object dat de fascinatie van het begerende subject gaande maakt. Puntig gesteld : het is de apriorivorm van het fascinans. Daarachter loert het dreigende Ding, de dodelijke verschrikking van de leegte, de verhulde en verwoestende kracht van het zwijgende niets, waarin het subject dat er zich aan overgeeft, vernietigd wordt en ophoudt subject te zijn. Dat Ding mogen we wellicht aanduiden als de grondvorm van het deinos.

Lacan ontwikkelde zijn theorie van het petit a niet in de eerste plaats aan de hand van het voorbeeld van de stem. Het was vooral de blik die eerst als objet a gearticuleerd werd. Daarbij liet hij zich inspireren door het late werk van zijn vriend, Maurice Merleau-Ponty. Die had, reflecterend over de perceptie en onder andere over de indruk die schilders vaak hebben dat de dingen hen aankijken, zelf een gedachtengang uitgewerkt volgens dewelke er tussen het zichtbare en het subject dat ziet een chiasme bestaat. Dat wil zeggen : in de perceptie is er een wisselwerking tussen het geziene object en het subject dat ziet, in die zin dat pas in de wisselwerking het subject als subject en het object als object ontstaat. Daarmee trok hij de consequentie uit zijn vroegere werk waarin hij reeds de perceptie wilde zien als een funderend, voor subject en object constitutief gebeu$\mathrm{ren}^{22}$. Lacan gebruikte de uiteenzettingen van zijn vriend over het lichaam - dat zowel een ziend als een gezien lichaam is - om zijn eigen begrip van de blik als objet $a$ te articuleren. Met blik bedoelt hij niet hetzelfde als wat wij het zien noemen : de blik is voor hem het niet-empirische object dat het zien onderspant, het niet-objectiveerbare object dat de beweging van het zien animeert, als het ware de apriorivorm van het begerende zien. Als objet $a$ kan de blik nooit tot het imaginaire teruggevoerd - of gespeculariseerd, in de bewoording van Lacan worden, omdat de speculaire of imaginaire logica reeds de aanwezigheid van een subject en een object vooronderstelt, en de blik eerder als de niet-empirische apriorivorm van het zien moet gedacht worden.

Nadat hij in aansluiting bij Merleau-Ponty's denken de blik tot centraal object had gepromoveerd, voerde hij ook de stem als objet $a$ in, hoewel Merleau-Ponty over de stem of over het horen weinig of niets had geschreven. Lacans theorie over de stem handelt ook niet over het horen, hij wil nu eenmaal geen fenomenoloog of filosoof zijn, maar enkel een psychoanalytisch denker ${ }^{23}$. Zoals we de blik als petit $a$ slechts met het schuine oog van de begeerte, dus slechts metaforisch - als ik dit woord hier mag gebruiken - kunnen zien, zo kunnen we ook de stem slechts met een metaforisch oor horen. De lacaniaanse stem valt alweer niet samen met de fenomenale stem die we horen, en er is ook geen directe causale relatie tussen de fenomenale stem en de stem als objet $a$. De stem als objet $a$ is 
dus niet wat we in de empirische werkelijkheid horen, maar een soort latente apriorivorm van het begerende horen. Ze wordt slechts door het oor van het verlangen gehoord. De stem als petit $a$ staat ook in directe relatie met het lacaniaanse Ding. Ze verschijnt immers niet als een gedachtelijk niets, als een puur abstracte vorm, ze moet steeds geïncorporeerd worden, belichaamd in een singuliere stem, die ook in de orde van het reële thuishoort. Men begrijpe dit correct in lacaniaanse zin: de singuliere stem is niet de stem als objet $a$, ze geeft er slechts gestalte aan door er, als om een leegte, omheen te cirkelen, door het nietobjectieve van het objet $a$ te omlijnen, door het niets ervan af te bakenen. En de singuliere belichaming ondergaat door toedoen van het petit a zo iets als een metamorfose : ze blijft niet een singuliere stem naast vele andere, ze wordt uniek en lijkt dan onvervangbaar : fascinans. De singuliere belichaming neemt ook het onverdraaglijke zwijgen weg, de dreigende stilte, die de Sirenen omgeeft, ze distantieert de vernietigende leegte die het Ding karakteriseert. Ze fungeert daarmee ook als een soort scherm, een verzachtingsmiddel, om met Nietzsche te spreken, een schone schijn die nog net iets laat horen van de totale leegte van het Ding, van wat we dus slechts zouden kunnen horen ten koste van ons eigen bestaan. Die schone schijn is het domein van Orfeus en de muzen. Hij klinkt op uit de verschrikkelijke stilte, zoals de muziek dat altijd doet. Zoals alle muziek heeft de stem voortdurend de stilte nodig en onderhoudt er een directe relatie mee. Muziek verbreekt de stilte, heeft haar nodig om haar te bezweren. Zonder stilte geen muziek.

Belangrijk voor mijn betoog is dat het lacaniaanse stem-begrip een plausibele verklaring biedt voor de onweerstaanbare fascinatie die van een werkelijke stem kan uitgaan. Voor wie - zoals ik - aanneemt dat de mens een wezen van begeerte is, dat door een onontkoombaar en onvervulbaar tekort wordt geconstitueerd, is de opvatting van de stem als objet $a$ inderdaad bijzonder aantrekkelijk. De stem als objet a kunnen we dan begrijpen als een gestalte - een apriori-vorm - van het gemis dat begeerte heet, en dat ons maakt tot wat we zijn. Het tekort dat ons voortdrijft, verleent aan de stem een niet eindigende en onweerstaanbare fascinatie. Het objet $a$ is de mogelijkheidsvoorwaarde voor de stem als fascinans en als deinos. Als scherm voor het vernietigende Ding komt het overeen met wat Nietzsche als het verzachtingsmiddel van het demonische omschreef.

Nog om een andere reden trekt me Lacans opvatting aan. De betekenis die we aan de werkelijke stem kunnen geven, is - in de lijn van Lacans denken - een zin die in het menselijk subject als begerend lichaam ingeschreven staat, en kan dus niet de 'geestelijke' zin zijn die er in de gebruikelijke dualistische opvattingen opgekleefd wordt. 


\section{Terug naar de stem van di Stefano en de los Angeles}

In een even gangbare als platte opvatting is de stem enkel maar een sonoor middel voor communicatie, een in de ruimte meetbaar golfmedium dat aan ideeen, gevoelens en voorstellingen een klankbeeld toevoegt. Dat klankbeeld is dan niet meer dan een puur instrumentele uiterlijkheid die geen betekenis constitueert, maar enkel betekenis overdraagt. We worden duidelijk aan Descartes herinnerd. De mooie scheiding tussen betekenaar en betekende, die de Saussure in het teken aanbracht, kunnen we ook als cartesiaans-dualistisch duiden. Een dergelijke opvatting van de stem voert rechtstreeks naar de verleidelijke romantische onzin die de stem en de muziek boven het stoffelijke verheft tot een etherisch, puur geestelijk medium dat, verlost van zijn lichamelijke banden, metafysische boodschappen uitdraagt. Een dergelijke opvatting is echter evident in flagrante tegenspraak met de feitelijke ervaring van de muziekliefhebber. Voor hem is de pure klank, de singuliere sonore kwaliteit van de stem immers op zichzelf betekenisvol. Voor hem is de eigen stemkwaliteit volkomen singulier, een sonoor portret van een persona, met een specifiek karakter en een eigen schoonheid, en in de zang is de stem niet enkel drager van een boodschap, zij is zelf reeds boodschap en ze heeft een volstrekt eigen, zinvolle fascinatie. De beluistering van de los Angeles of di Stefano is voor de muziekliefhebber reeds een bevrediging op zichzelf.

Toegegeven, zulk een muzikale fascinatie geldt niet uitsluitend voor menselijke zangstemmen. Ik sluit me aan bij de overtuiging van wellicht alle muziekliefhebbers, wanneer ik het muzikale klinken van een instrument of van een instrumentaal ensemble als een tweede, door technisch vernuft afgeleide, vorm van muzikale klankproductie, en het zingen dus als de oervorm van elke muzikale activiteit zie. Wat geldt voor de singuliere klank van een zangstem, voor de los Angeles of di Stefano, geldt dan evenzeer voor de specifieke klaviersonoriteit van Claudio Arrau of Wilhelm Kempff, voor de ranke precieze viooltoon van Jascha Heifetz of de lyrisch-gevoelige toon van Fritz Kreisler, voor de bronzen sonoriteit van het Concertgebouworkest of de voluptueuze klank van de Berliner. In al deze gevallen gaat het om de ervaring van een somatisch-zintuiglijke klanktegenwoordigheid, en ook de louter instrumentale muziek die elke band met het zingen en met het woord heeft opgegeven, woont in wat je de ruimte van het objet a kan noemen, in de ruimte waarin volgens Blanchot het echte zingen nog moest komen.

Je kan het objet $a$-begrip nog veel ruimer toepassen. Je zou er misschien elke schoonheidservaring mee kunnen verhelderen. Als ik op wandel in het bos plots bekoord word door een lichtinval, door het hoge fluiten van een vogel of door een vlinder die op een bloem neerstrijkt, dan komt dat wellicht, omdat ik uit mezelf word weggerukt om even door het andere gegrepen te worden vanuit mezelf, 
vanuit mijn eigen constitutief tekort, met andere woorden, door het petit $a$. Op die manier zou je enig fundament kunnen verlenen aan de intuïtieve overtuiging die door velen - onder andere door Nietzsche en Freud - werd uitgesproken, dat de schoonheidservaring in het erotische (lichaam) wortelt.

Is het concept objet $a$ uitstekend geschikt om de fascinatie van een stem te laten begrijpen als module van het onopvulbare gemis dat ons doet leven, dan schiet het begrip mijns inziens toch in menig opzicht tekort om onze muzikale ervaring afdoende te verhelderen. Daarmee bedoel ik niet dat het concept zelf foutief of onbruikbaar zou zijn, maar enkel dat het niet geschikt is om dingen te verhelderen waarvoor het nu eenmaal niet bedacht werd.

Het begrip objet a werd namelijk in zijn toepassing op de stem niet bedacht om het singuliere, de unieke incorporatie van een bepaalde empirische stem te betekenen. Die singuliere belichaming, de heel eigen klank van de stem van de los Angeles of di Stefano, ontsnapt weliswaar niet aan de betekening door het petit a, maar ze wordt er ook niet in haar singulariteit door betekend. En het is precies deze concrete belichaamde singulariteit waarmee $i \mathbf{k}$ in de luisterervaring heb te doen. Het is precies in deze bijzondere sonore vorm dat het objet a mij kan treffen en mij van de los Angeles en di Stefano doet houden.

Ik tracht dit met een analogon te verduidelijken. Als je verliefd wordt op een vrouw, kan je zeggen dat zij de plaats van het objet a heeft ingenomen. $Z \mathrm{ij}$ is niet het petit $a$, ze vult het tekort ervan niet op, want dat tekort kan, zoals we weten, niet opgevuld worden. $\mathrm{Zij}$ is enkel verschenen in de ruimte van je tekort, en haar volkomen singuliere gestalte, haar figuur, haar ogen en haar glimlach, haar stem en haar handen en haren, al datgene waarvan je wellicht - in je onwetendheid of zelfbedrog - kan beweren dat het je verliefd heeft gemaakt, heeft zijn onweerstaanbare aantrekkingskracht slechts aan de onuitputtelijkheid van je tekort, aan het objet $a$ dus, ontleend. Toch is die volstrekt singuliere belichaming voor jou wel degelijk essentieel. Je kan je in de tijd dat je verliefdheid of je liefde duurt, zelfs niet voorstellen dat een andere vrouw, een andere singuliere belichaming, dezelfde plaats van het objet a zou kunnen innemen. Daarin vergis je je dan wel, want dat onvoorstelbare blijkt wel degelijk mogelijk te zijn. De concrete singuliere belichaming vervult een essentiële functie, maar ze kan na verloop van tijd door een andere vervangen worden. $Z o$ is dat in het leven nu eenmaal.

Zo kan het de muziekliefhebber ook met stemmen vergaan, of, ruimer bekeken, ook met andere vertolkers, of met bepaalde muzikale werken of componisten. Je hebt er eens van gehouden, maar nu hou je alleen maar een gevoel van respect of ten hoogste bewondering over. Zo is mij dat als muziekliefhebber met de stem van de grote D. Fischer-Dieskau vergaan. Een liefde kan afstervan en plaats maken voor een nieuwe vlam, die dan op haar beurt de ruimte van het $o b$ jet $a$ inneemt. Je anamorfotische oor kan, net als je anamorfotische blik, verschuiven naar een andere stem. En dat is wat in de ervaring van de melomaan 
ook vaak genoeg gebeurt : als je een nieuwe stem hoort, kan het gebeuren dat je er plots echt van houdt. Zoals het kan gebeuren dat je liefde verzwakt en door een andere stem opgewekt wordt. Meestal zijn er slechts weinig stemmen, zo lijkt me, waar je een leven lang van houdt. Telkens blijft echter de volstrekt singuliere sonoriteit van een zanger(es) een essentieel element van je voorkeur. En precies dat singuliere wordt door het objet a natuurlijk niet verklaard. Individuum est ineffabile. Het volstrekt singuliere is op geen enkele wijze betekenbaar of articuleerbaar. En zeker niet het singuliere van een stem. Voor de auditieve ervaring hebben we immers vrijwel geen woordenschat, we moeten ons behelpen met woorden uit de visuele of motorische sfeer, of met linguïstische termen - zoals betekenaar - om ze metaforisch op het auditieve over te dragen ${ }^{24}$. Maar dan missen ze altijd ook precisie en adequatie. De taal, en dus het denken, glijdt steeds al los en onzeker heen over wat ze wil vasthouden, over alles wat zintuiglijksomatisch verschijnt, over de concrete anderen, de concrete dingen, kortom over het werkelijke andere, en dat lijkt me in nog sterkere mate voor het auditieve dan voor het visuele te gelden, omdat we daar vrijwel geen woorden voor hebben. Zonder taal zouden we over niets kunnen spreken of denken, en zouden de dingen ook een andere - uiteraard strict onzegbare - betekenis hebben. Maar dat betekent nog niet dat elke zin volledig door de taal geconstitueerd wordt. Wie over muziek reflecteert, tast de grenzen van de taal en van de filosofie af.

Op nog een andere wijze kan het begrip objet a niet adequaat zeggen wat er zou moeten gezegd worden. Als apriori is het immers een transcendentaal begrip dat slechts een mogelijkheidsvoorwaarde inhoudt, maar dat het concrete van een particuliere ervaring niet kan uitzeggen. Ell weer kan het analogon van de verliefdheid verhelderend werken.

Wanneer je verliefd bent, is er slechts één enkele, één unieke die de - onhoudbare - belofte vertegenwoordigt dat ze je tekort zal opvullen : ze wordt dan ook onvervangbaar. ( Uiterst zeldzaam zijn er ook wel eens twee, waartussen je hart dan balanceert. Maar het zijn er niet verscheidene tegelijk.) Met de zangstemmen is dat niet zo. De stem van di Stefano of de los Angeles vult niet op volstrekt onvervangbare manier een leegte op. Ze wordt nooit echt onmisbaar, want je kan ook van Bergonzi of Lisa de la Casa, en zelfs van verscheidene tenoren en sopranen houden. Weliswaar blijven de los Angeles of di Stefano een unieke waarde behouden, maar dan weer niet volkomen uniek. Op de keper beschouwd dus niet echt uniek. De melomaan is een rijk mens : hij kent vele unieke liefdes. Op het terrein van de werkelijke menselijke verhoudingen kan zo iets vermoedelijk niet waargemaakt worden. Op het esthetische terrein is het heel gewoon.

Er is nog een verschil. Als je houdt van een vrouw, wens je niet dat anderen evenzeer van die vrouw zouden houden, want je wilt die vrouw niet met anderen delen. Dat wil je precies wel, wanneer je van een stem houdt. Tot je liefde voor 
die stem behoort tevens de wens dat velen van deze stem zouden houden. Je bent er zelfs des te gelukkiger mee, wanneer je liefde door velen gedeeld wordt. En meestal is dat ook het geval : het aantal muziekliefhebbers die zoals ik van di Stefano en de los Angeles houden, moet nog steeds in de duizenden lopen.

De verklaring voor deze twee punten van verschil kan wellicht aangereikt worden door het begrip sublimatie. Sublimatie kan men misschien paradoxaal een voor de mens natuurlijke denaturatie van de begeerte noemen. Het gesublimeerde verlangen is niet meer hetzelfde als het oorspronkelijke verlangen : het werd opgeheven, op een hoger vlak getild, zoals het veelal heet. Het is een getransformeerd verlangen - en weer zou ik hier graag van een metamorfose spreken. Met de objecten van je gemetamorfoseerde begeerte kan je een gul spel spelen, je hebt er geen imaginair-narcistische of obsessieve band mee en je kan ze delen met en geven aan anderen. Het niet-gesublimeerde tekort daarentegen laat evenmin als de Sirenen met zich spelen, het speelt veeleer met jou. De begeerte als tekort houdt steeds het mogelijke gevaar in dat we ten prooi vallen aan de verschrikking van het demonische, van het vernietigende Ding. Gesublimeerd echter heeft de begeerte het nietzscheaanse verzachtingsmiddel ingenomen. De sublimatie maakt een minder door het imaginaire getekende levenswijze mogelijk, en creëert ruimte voor spel en vrijgevigheid. Daarom wil ik mijn liefde voor de los Angeles en di Stefano royaal met anderen delen. Ik sta vrij tegenover hen, en hoe groter mijn liefde voor hen is, hoe gulhartiger ik anderen deelgenoot van mijn liefde wil maken : ik kan mijn liefde spelend ten geschenke geven zonder het gevoel te hebben dat ik iets opoffer. Dat lijkt me typisch voor de esthetische ervaring en het vormt er ook de unieke waarde van : het maakt de esthetische ervaring tot een utopie van het ethische leven. De esthetische ervaring is een surplus van ons bestaan, een toegift, een pure luxe, een geschenk van Orfeus en de Muzen, de winst in een spel dat je niet hoeft te winnen, en dat je niet eens kan verliezen.

\section{Noten}

${ }^{1}$ Rudolf Otto: Het heilige, Antwerpen, De Branding en Hilversum, De Boer/Paul Brand, 1963 , p. 37.

${ }^{2}$ Ibid. p. 45.

${ }^{3}$ Enkele van deze verwijzingen ben ik verschuldigd aan Bernard Baas : De la Chose d̀ l'objet. Jacques Lacan et la traversée de la phénoménologie, Leuven, Peeters-Vrin, 1998. De tekst van Rousseau luidt : "Conscience! conscience! instinct divin, immortelle et céleste voix"; zie : Emile, Paris, Garnier-Flammarion, 1966, p. 378. Voor Kant, zie : Kritik der praktischen Vernunft, Deel I, Boek 1, Hoofdstuk 1, § 2, Anmerkung II. Voor Heidegger zie : Sein und Zeit, $\S 56$ tot en met 58.

${ }^{4}$ Ik citeer naar de vertaling van M.A. Schwartz, Amsterdam, Athenaeum-Polak \& Van 
Gennep, 1981. Citaten op p. 527-530.

${ }^{5}$ Max Horkheimer-Th.W. Adorno, Dialectiek van de Verlichting, Nijmegen, Sun, 1987. Citaten op p. 69-75.

${ }^{6}$ Maurice Blanchot, 'Le chant des Sirènes', in : Le livre à venir, Paris, Gallimard, 1959, heruitgegeven in Collection Idées, 1971, p. 9.

${ }^{7}$ Ibid. p. 12.

${ }^{8}$ F. Nietzsche, Die fröhliche Wissenschaft, Zweites Buch, 84, KSA-uitgave, Band 3, p. 440-4l. Ik gebruik de Nederlandse vertaling van Pé Hawinkels, Amstedam, Arbeiderspers, 1992, p. 96.

${ }^{9}$ F. Nietzsche, Also sprach Zarathustra, KSA. Band 4, p. 280.

${ }^{10}$ Ibid. p. 291.

${ }^{11}$ Euripides, Hippolytus, vers 84-86. Vertaling van De Waele, Antwerpen, Nederlandsche Boekhandel, 1948.

${ }^{12} \mathrm{Ik}$ ben één en ander verschuldigd aan het mooie boekje van W.F. Otto, Die Musen und der göttliche Ursprung des Singens und Sagens, Darmstadt, Wissenschaftliche Buchgesellschaft, 1971.

${ }_{13}^{13}$ Volgens een verloren gegane hymne van Pindaros. Zie W.F.Otto, p. 28.

${ }^{14}$ Plato : Phaido, 61 a. De vertaling van Xaveer de Win : de hoogste vorm van muziek (in Verzameld Werk, band 1, Nederlandsche Boekhandel, Antwerpen, 1962, p. 935 ) lijkt me minder geslaagd dan die van W.F. Otto. Het Griekse woord mousikè is niet zonder sterke nuances met ons muziek gelijk te stellen. Zie T. Georgiades, Musik und Rhythmus bei den Griechen. Zum Ursprung der abendländischen Musik. Rde, Hamburg, Rowohlt, 1958.

${ }^{15}$ W.F. Otto, ibid. p. 34. Otto verwijst naar het voorbeeld van Hesiodos, die voor zijn Theogonie een bijzonder lange inleiding schreef waarin hij zijn ontmoeting met de Muzen, die hij niet zag, maar wel hoorde, wilde bezingen. Otto verzet zich tegen commentatoren die deze inleiding niet bijzonder relevant vonden, en wijst erop dat voor de dichter het horen van de Muzenstem essentieel was.

${ }^{16}$ Geciteerd naar Rüdiger Safranski, Heidegger en zijn tijd, Antwerpen/Amsterdam, Atlas, 1995, p. 410.

${ }^{17}$ Karl Kerenyi, Griekse heldensagen, Zeist, Phoenix Pocket, W. De Haan N.V. \& N.V. De Standaard, 1962, p. 192.

${ }^{18}$ Voor een vollediger uiteenzetting over het objet petit $a$ en de stem verwijs ik de lezer naar Bernard Baas, De la Chose à l'objet. Jacques Lacan et la traversée de la phénoménologie, Leuven, Peeters-Vrin, 1998. Vooral het laatste deel : 'Lacan, la voix, le temps', p. 149-253, is voor mij een belangrijke bron geweest.

19 Voor het Franse le désir gebruikt men in het Nederlands veelal het verlangen, vermoedelijk omdat daarin nog iets doorklinkt van het Duitse der Wunsch. Ik geef zelf de voorkeur aan de begeerte, omdat in dit woord het libidinale, erotische karakter duidelijker gesuggereerd wordt. Slechts af en toe gebruik ik, ter afwisseling, het woord verlangen.

${ }^{20}$ In zijn Quatre concepts fondamentaux de la psychanalys, Le Séminaire, Livre XI, verwijst Lacan naar het bekende anamorfotische object. Het beroemde doek van Hans Holbein, "The Ambassadors" - in de National Gallery, London -, illustreert de anamorfose, een niet zelden gebruikt motief in de schilderkunst. Onderaan in het midden van het doek is een vreemd, langwerpig, ovaal voorwerp te zien, dat de kijker niet kan thuisbrengen. Slechts wanneer de bezoeker de zaal langs links verlaat en dan terug opkijkt naar het 
doek, kan hij met een schuine blik het bevreemdende voorwerp als een doodshoofd herkennen.

${ }^{21} \mathrm{~B}$. Baas beklemtoont dat het petit a niet als een echt transcendentaal kan beschouwd worden, maar dat het slechts als dusdanig fungeert. Zie Baas, op. cit. p. 83-86.

${ }^{22}$ Zie vooral M. Merleau-Ponty, 'L'oeil et l'esprit', in: Les Temps Modernes 184-85, 1961, p. 193-227, in 1964 heruitgegeven door Parijs, Gallimard, Nederlandse vertaling : Oog en Geest, Baarn-Ambo, 1996 ; en verder : Le visible et l'invisible, Paris, Gallimard, 1964, p. 172-204 en p. 314-315.

${ }^{23}$ Met het thema van de stem als objet $a$ is het moeilijk gesteld, omdat de betreffende teksten nog niet uitgegeven zijn en slechts als steno-notities bestaan. Zie B. Baas, op. cit. p. 176 en vlg.

24 Ik ga nader in op deze problematiek in Metamorfose. Een filosofie van de muziek, Leende, Damon, 1999, p. 53-70. 